\title{
Research on the International Strategy and Technology Export Modes of Technological Enterprises
}

\author{
Lan Wang \\ School of Business, Beijing Language and Culture University, Beijing, China \\ Email:im2003@163.com
}

Received 9 December 2015; accepted 22 December 2015; published 25 December 2015

Copyright (C) 2015 by author and Scientific Research Publishing Inc.

This work is licensed under the Creative Commons Attribution International License (CC BY). http://creativecommons.org/licenses/by/4.0/

c) (i) Open Access

\begin{abstract}
The quantity and quality of international technologies reflect both the ability of independent innovation and the application potential of the products in the international market, measuring the technology innovation capacity and the international comprehensive competitiveness. Based on the data from Zhongguancun area, this thesis analyzes the current situation and problems of international strategy and technology export modes of technological enterprises. And furthermore, we put forwards the suggestions to improve technology internationalization of technological enterprises. The government should support the collaboration between domestic enterprises and foreign companies in the development of new technologies, support the technology exports, support the enterprises to apply for foreign patents and join the formulation of international standards, and establish international intellectual rights and standard formulation platform.
\end{abstract}

\section{Keywords}

International Strategy, Technology Innovation, Technological Enterprises, Technology Export Modes

\section{Introduction}

At present, China's economic development has entered a new normal condition. The mode of economic development is shifted from the rapid growth to medium-speed growth, and from the scale model of extensive growth to a mass efficiency type of intensive growth. The economic structure is experiencing a deep adjustment from the incremental expansion to the coexistence of adjusting the stock and optimizing the incremental. The economic development momentum is shifting to a new growth point from the traditional growth. Innovation is the 
key driver to adapt to the new normal and to lead the new normal. Only by enhancing the capability of independent innovation and the capturing, a number of key technologies can promote rapid development of new industries, becoming the growth point that supports economic development pattern and structural adjustments. The re-manufacturing strategy will affect the international development of our traditional industries. Developed countries came up with the re-manufacturing strategy and focused on high-end manufacturing, which would bring a readjustment of the global supply chain. China does not only face the challenge of traditional labor-intensive industries with other developing countries, but also faces challenges of high-end manufacturing with developed countries, especially those industries that own big scales and master general technologies. The quantity and quality of international technologies reflect both the ability of independent innovation and the application potential of the products in the international market, measuring the technology innovation capacity and the international comprehensive competitiveness [1].

\section{Theory}

\subsection{The theory of Technology Localization}

In 1983, British economist Lall proposed technology localization theory in the "The new multinationals: The spread of third world enterprises”. This theory claimed that the enterprises in developing countries can not only imitate advanced technologies, but also can largely adjust parts of the technologies. The process of technology localization generates competency to multinational companies in developing countries. Although the technology features in transnational companies in developing countries are small-scale, technology-standardized and labor-intensive, the formation of this technology contains internal innovation of the enterprises. The technology of localization not only emphasizes on the competency of enterprises from developing countries, but also focuses on the innovative activities that generate competitive advantages, leading the concentration of developing countries from direct investments to micro levels. Compare to the theory of small-scale technology, Lall focused more on the innovation and regeneration of the imported technologies, emphasizing that the acceptance and improvements of imported technologies are not passive imitating and copying, but are the absorption and innovation of technologies, by which brought competitive advantages to enterprises [2].

\subsection{Symbiosis Theory}

The symbiosis model in internationalization refers to a new collaboration of SMEs and big multinational companies. This collaboration is featured with interdependence. Companies are interdependent in a sustainable way. To large companies, they obtain greater elasticity and efficiency through the integration with small companies, and they provide opportunities for small companies. By meeting higher level needs of large scale companies, small enterprises become more specialized and achieve the economy of scale. The pressure under globalization pushes large scale companies to decrease costs by better specialization. Since large scale companies often acquire specialization by outsourcing, small businesses have symbiotic relationships with big companies. The symbiotic relationship makes it quicker and more efficient for technological enterprises in Beijing to upgrade their expansion area and efficiency. Symbiotic cooperation can emerge at anywhere in a supply chain in many ways. By the cooperation with large multinational companies, private technological companies in Beijing can be partially protected from fierce competitions with companies that are bigger and more efficient. Bonaeeorsi (1992) [3] explained how small companies depend on big companies in the process of internationalization. During the procedure of "expand proportionally", small companies can utilize the leverage theory to decrease time consuming, costs and risks of internationalization. Similarly, small companies that are employed to perform special functions in big companies can accelerate small companies' learning curves and obtain more international professions, becoming more competitive in the global market.

For technology enterprises in Beijing, there are two situations of symbiotic model in their internationalization. One of the situations is that these enterprises coexist with large transnational companies. For example, these companies unite with transnational companies and take part in the supply chain distribution or licensing. The second situation is that these technology companies coexist with big domestic companies, joining large enterprise groups. On the one hand, the small companies can acquire capital and technology support from large enterprises and small companies can produce supporting products and spare parts for big companies, becoming the outsourcing companies of a big production system and forming cooperative relationship to exert the advantages 
of small businesses' agility [4] [5]. On the other hand, companies adopt the following strategy and attach to those successful international companies, entering the international market by the aid of established foreign sales channels and the ability to operate [6] [7].

\section{The Current Situation and Problems of Technology Internationalization}

In recent years, under the instruction of founding innovative enterprises of and the focus on technological innovation of Chinese enterprises, the gross amount of international trade in technology grows gradually. As the leader of national technology research and innovation, the technology enterprises represented by those in Beijing draw the attention of investors and scholars.

\subsection{International Technical Field}

In recent years, the exports of technical products in Beijing mainly concentrated in fields of computer and communication technology with significant advantages, becoming the main force of exports in technology enterprises in Beijing. According to the technology industry in Beijing, information technology has been a traditional advantageous industry in Beijing, including software, hardware and communication technology. Also, Beijing has been using available resources to enforce the advantage. Many of the technology enterprises in Beijing are located in Zhongguancun, including some leading companies such as Lenovo, Founder and Tsinghua Tongfang Science and Technology etc. According to the technology field in exports, the total amount in 2014 is the same as that in 2013 in Zhongguancun. Information and advanced manufacturing technologies are still the most focused fields in foreign trade. The new energy field ranks number three, exceeding the new material field. Under the background of developing production service industry and advanced manufacturing in Beijing, information technology manufacturing that focuses on computer and communication technology and information services that focus on software will see a better prospect of development. This development will promote the development of high-tech industry in Beijing, the distribution in internationalization, resource allocation and maximization of the profits.

The outsourcing projects of Beijing are concentrated in Asia and Africa, leading to the exports of many domestic equipment, materials and technology. In the fields of traffic, railway, communication, radio and television network, China has shown strong features of technology and intelligence exports. Expatriates are mostly professionals from engineering technology, business management, computer software design and maintenance, engineering design and consulting and other fields.

\subsection{Technology Export Modes and Regional Distribution}

Since the environment of innovation development of technology enterprises in Beijing is improved, the technology trade became more active. The internationalization of technology enterprises in Beijing is basically in the process of exporting and importing products while importing advanced foreign technology and capital. Specifically, the export number of technological products is growing and the prospect of attracting foreign investments and research centers is booming. Many of the technology enterprises in Beijing, especially foreign companies, became the production location of global exports for multinational companies based on their advantages of low costs on production and labor. At the same time that the export scale of technology enterprises' products in Beijing is larger, the exports of independent intellectual property products improve the technology intensity of export products. The technology enterprises in Beijing are involved in technology trades with mostly developing countries, demonstrating that the technology enterprises in Beijing are more technological advantageous than other developing countries. The growth of technology contracts turnover slowed down in recent two years. According to the data from Zhongguancun technology companies, the turnover of technology contracts in 2013 was 51.49 billion RMB, whereas the turnover of technology contracts in 2014 decreased to 34.769 billion RMB.

\subsubsection{The Exports of Technology Are Mainly in Technology Services and Developments}

Many technology enterprises in Beijing have mastered some patents and professional techniques, and have been prepared with conditions of exporting, thus technology exporting has become a method of internationalization. In recent years, Beijing has developed rapidly in technology trading, including technology development, technology services, technology licensing, and collaborative production of equipment sets or critical equipment. 
This operation mode is a contract oriented international mode, providing low-risk and low-investment opportunities for small companies to enter the international market with stable income. This method can also rapidly improve the reputation of companies and their products, as well as the occupancy rate of the market, in order to accumulate intangible assets. In the constitution of contract types, technology exports contracts use technology services and technology development as the main formats. According to the data from Zhongguancun, there were 383 technology services contracts in 2014, and the turnover rate was 20.486 billion RMB. Meanwhile, 467 technology development contracts generated 14.207 billion RMB. These two categories ranked top and the second places, while the technology development has risen by $42.21 \%$ and the technology services decreased by 53.21\% (Table 1).

\subsubsection{Diversified Technology Export Target Countries}

In 2014, the export target countries are diversified, covering Europe, Asia, Africa and Northern America and including both developed countries and developing countries. Because of the improvement of competency and adjustments of strategies, the export countries change over time, extending to new trade partners. For example, in Zhongguancun, the top ten export countries of the turnover rate in technology export are Finland, America, Netherlands, Algeria, Belarus, Bangladesh, Laos, Sweden, Singapore and Equatorial Guinea. Compared to 2013, the top ten ranks changed significantly with only America and Belarus remained in the list in 2014.

\subsection{International Patent Application and Authorization}

The international patent application and authorization in technology enterprises in Beijing remained stable growth rates in recent years. The technology enterprises in Beijing pay more attention to the significance of international patents in global competitions, and companies' ability of innovation and application improves accordingly. Specifically, the growth rate of foreign patents is faster than that of the Beijing area, and the proportion of foreign patents can be increased substantially. According to the data from Zhongguancun, in 2014, foreign authorizations of valid patents held by enterprises reached to 2964 items, and foreign authorizations of valid invention patents held by enterprises counted 2852 items, increased by $39.9 \%$ and $43.2 \%$ respectively. It was the first time that the number of foreign patent accounted for more than $3 \%$ of total valid patents. From the constitution of these patents, international patents are still comprised mostly by invention patents. In 2014, the foreign invention patents accounted for $96.2 \%$ of the total number of foreign authorized patents.

\subsection{Current Problems}

\subsubsection{The innovation Capability of the Companies Should Be Improved}

The technology enterprises in Beijing have not yet formed industry groups that have independent core technologies and international competency. Except for the aerospace industry, industries are inclined to homogenization and are lack of characteristics. Compare to developed countries, except that Beijing is the leading force in aerospace technology in the world, many of the other industries are at the level of application and integration innovation, falling short of fundamental and revolutionary innovation. The production of computers and mobile phones in Beijing ranked top, and the income of software and integrated circuit design accounted one-fifty and

Table 1. The components of technology export contracts in Zhongguancun in 2014.

\begin{tabular}{|c|c|c|c|c|c|}
\hline \multirow[b]{2}{*}{ Contract types } & \multicolumn{2}{|c|}{2013} & \multicolumn{3}{|c|}{2014} \\
\hline & $\begin{array}{c}\text { Number of } \\
\text { contracts }\end{array}$ & $\begin{array}{l}\text { Turnover rate } \\
\text { (billion) }\end{array}$ & $\begin{array}{c}\text { Number of } \\
\text { contracts }\end{array}$ & $\begin{array}{l}\text { Turnover rate } \\
\text { (billion) }\end{array}$ & $\begin{array}{c}\text { The growth rate of the } \\
\text { turnover rate (\%) }\end{array}$ \\
\hline Technology development & 470 & 10.237 & 467 & 14.207 & 42.21 \\
\hline Technology transfer & 11 & 0.062 & 14 & 0.034 & -45.16 \\
\hline Technology consultancy & 18 & 0.104 & 23 & 0.043 & -58.65 \\
\hline Technology services & 317 & 43.781 & 383 & 20.486 & -53.21 \\
\hline Total & 816 & 54.185 & 887 & 34.769 & -35.54 \\
\hline
\end{tabular}

Notes: Data from Zhongguancun management committee. 
one-sixth in China. However, many companies are still manufacturers but not inventors. Therefore, enterprises with core technologies and reputable brands should be supported [8] [9].

\subsubsection{The Technology Innovation Platform Should Be Improved}

Firstly, the technology innovation platform is not complete. Although there are many public laboratories built in Beijing, and the collaboration of production, learning and research is encouraged, the technology innovation platform should be further completed. Secondly, the information communication platform is not complete. During the investigation, the interviewed companies pointed out that they are lack of information on foreign investment environment and foreign project sources, the information on exporting and administrative approval process, as well as government supports and intermediary services information that companies are eager to obtain. Thirdly, the intellectual property platform is not yet completed. Under the circumstance that the intellectual properties are not paid enough attention in China, the lack of protection of intellectual values makes it difficult for enterprises to safeguard their rights, and the foreign companies are also worried that the technology spillover cannot gain proper protection. Fourthly, the intermediary service platforms are at their initial stage. A complete intermediary system, containing for-profit and non-profit organizations, is important for the innovation, industrialization and internationalization of enterprises. For example, the German government authorizes some industry related responsibilities to associates and organizations. Every organization is responsible for industry innovation and alleviates the country's pressure by sharing workloads. Also, many for-profit and non-profit organizations are promoting the industrialization of innovative technologies. So far, many companies in their start-up period closed because they are not industrialized, and many innovations are lack of promotion and capital support. Many companies have little knowledge on how to conduct internationalization, revealing that the current intermediary organization only shows little function [10] [11].

\section{Policy Suggestions on Supporting the Enterprise Technology Internationalization}

Technology communication and collaboration affect the cultivation of enterprise's competency, and the technology internationalization is the main content of enterprise's internationalization. Enterprises should adapt to the technology globalization and improve the collaboration with advanced innovation organizations to get involved in the global innovation network. Enterprises can raise their positions in the innovation system by enhancing the innovation capability. The government should establish a complete innovation system to provide technology source for SMEs. Many traditional SMEs and some high-tech companies are insufficient in innovation capability and in need of innovation equipment. The government needs to build a platform that can connect the research institution and intermediaries with the entities in need of technology. By professional developments, the research institutions can absorb and re-innovate the advanced technologies (some of the re-innovation is done by both the enterprises and research institutions), transferring the technology to SMEs for industrialization. Developed countries such as Germany and Japan have such mature innovation systems, and these systems play significant roles in obtaining international advantages for enterprises. Taiwan is famous for "import, absorb and re-innovate". At the beginning of the technology industry development, the companies in Taiwan are encouraged to learn from foreign companies. They accelerate their progress in independent innovation and force the industrialization of research results, establishing a number of companies with independent property rights and international competency.

\subsection{Support the Collaboration between Domestic Enterprises and Foreign Companies in the Development of New Technologies}

The government should support the technology companies in Beijing to cooperate with institutions of higher learning and institutions of researches, strengthening the collaboration with reputable laboratories and research institutions and establishing research centers to develop influential technologies and products. The government should enlarge the support of capital and lead the companies to join international collaborative research projects, improving the capability of following the trend and innovations. The government ought to unite the technology department to select some innovative projects, and invite international research institutions to cooperate with local companies and universities to develop technologies. 


\subsection{Support Companies to Enlarge the Imports}

The government should strengthen the technology collaboration to master the knowledge of advanced technology researches, and select some technology fields that are suitable for domestic companies. By collaboration and products imports, the companies can obtain advanced technology and talents. Companies should be supported in the absorption of imported technology, in order to promote new innovation results and lead the innovation research of related industries. The government should financially support the companies that acquire re-innovation by learning and researching.

\subsection{Support the Technology Exports}

Beijing should establish a technology export registration system to improve the services of technology exports. By improving the support of capital, the government should encourage more companies to export technology services. The government should hold international technology communications, support enterprises to join international technology fairs and prestigious forums, support the intermediary institutions that are involved in technology exports, and improve the service systems of law and finance.

\subsection{Support the Enterprises to Apply for Foreign Patents and Join the Formulation of International Standards}

The government should strengthen the connection with international patent institution and other standard formulation institutions, and host related international conferences. The officials should understand the rules and knowledge of international patents and standard management, in order to offer professional services to enterprises. The government should improve their financial support for companies to apply for foreign patents and reduce the cost of companies by all means, encouraging more companies to transfer the technology innovations to international patents and standards to improve the influence of the technology innovation in Beijing. Under the economic globalization, international standards are more important for the international development of enterprises. The maker and the follower of the rules are treated differently. For SMEs, the products must follow the national export standards and regulations to improve the competency in the market. Technology companies in developed countries have the advantages of technology innovation, so they can control the standard making and conduct the application of international utilization of the standards, occupying the positions of standards formation and obtaining profits by the strategy: technology patent-patent standardization-standard globalization to control the foreign market. For example, America has established many international technology standards for the Internet decades ago, requiring other countries to follow its standards as the national regulations and charging fees. Japan and Korea have the technology advantages in flat panel display, so they come up with new working proposals constantly and occupy most of the international standards. Some countries that have no core technologies and are not involved in international trade unions have to pay for patents and standards to the union, thus the profits are decreased.

\subsection{Establish International Intellectual Rights and Standard Formulation Platform}

Establish international intellectual rights and standard formulation platform, is to utilize demonstrative methods to promote influential innovation, the technology standard formulation and internationalization, as well as upgrading the level, quality and influence of technology enterprises in Beijing. The encouragement policies should be improved to support the output of high quality patents invention and basic innovative intellectual properties. The protection system of intellectual rights should be improved, and the international campaign on the protection of intellectual properties should be strengthened to eliminate related worries. The platform should respect and protect intellectual properties effectively to display the value of them and encourage technology companies in Beijing to learn from global leading enterprises and compete by intellectual properties. The government should let related intellectual property and international standard organizations to develop in Beijing. The officials should also establish authorization platforms to support enterprises in formulating standards and examining technology services. By encouraging the technology industry alliance in Beijing, especially new industry representative to take part in the making of industry, national and international standards, as well as holding influential standardized activities, the government should continue to encourage and support the work of committees in conducting the formulation of technology standards. 


\section{Conclusions}

This study reveals the status of technology internationalization of Beijing technology companies. To enhance the competence, the technology companies in Beijing should strengthen the strategic collaboration with transnational companies. In order to improve the spill-over effect of technology in foreign companies and to improve the capability of independent innovation, the government should encourage and support the companies in Beijing to join the global innovation network of transnational companies. The government should also encourage the technology research by foreign companies, research institutions and companies in Beijing. Meanwhile, the research basements should be built, talents should be educated and intellectual properties should be shared. Moreover, the projects brought up by qualified foreign companies and domestic institutions (domestic companies, search institutions and universities) should be encouraged and supported.

Technology companies largely improve the collaboration, efficiency and performance of innovation by establishing innovative cooperation, innovative alliance, and sharing problem-solving platform and resources. Beijing should follow the trend of open innovation and complete an open platform for collaborative innovation for technology companies in Beijing. Firstly, the platform will depend on the radiation effect of Beijing in China and in the world. It should conduct united innovation of technology and business mode, promote the internationalization of innovation factors and the resource flow, and be involved in the global innovation network. Secondly, the platform should improve the collaboration with other areas in China and foreign institution, and improve the ability to integrate global resources. Thirdly, the platform should make use of the advantage of innovation resources, promote the sharing of multiple resources, establish innovative platforms and promote the collaborative innovation of institutions, universities, enterprises, talents, organizations and the government. For some projects of core technology, the platform should provide matching support by recruiting talents from enterprises, universities and related unions. The platform should make use of the radiation effect of Beijing in the technology innovation to promote international communication and collaboration.

\section{Acknowledgements}

This research is supported by Beijing supporting Central University joint project-Young Talent Plan (Project No. YETP0880), and Humanity and Social Science foundation of Ministry of Education of China (Project No. 15YJC630123).

\section{References}

[1] Johanson, J. and Wiedersheim-Paul, F. (1975) The Internationalization of the Firm-Four Swedish Cases. Journal of Management Studies, 12, 305-322.

[2] Lall, S. (1983) The New Multinationals: The Spread of Third World Enterprises. John Wiley \& Sons, New York.

[3] Bonaccorsi, A. and Lipparini, A. (1994) A Strategic Partnership in New Product Development: An Italian Case Study. Journal of Product Innovation, 11, 134-144.

[4] Rao, P.M. (2001) The ICT Revolution, Internationalization of Technological Activity, and the Emerging Economies: Implications for Global Marketing. International Business Review, 10, 571-596.

[5] Goerzen, A. and Beamish, P. (2003) Geographic Scope and Multinational Enterprise Performance. Strategic Management Journal, 24, 1289-1306. http://dx.doi.org/10.1002/smj.357

[6] McKiernan. P. (1992) Strategies of Growth: Maturity, Recovery and Internationalization. Routledge, London.

[7] Baden-Fuller, C. and Haefliger, S. (2013) Business Models and Technological Innovation. Long Range Planning, 46, 419-426. http://dx.doi.org/10.1016/j.lrp.2013.08.023

[8] Stefano, D., Matias, R. and Joe, T. (2014) Creating and Capturing Value from External Knowledge: The Moderating Role of Knowledge Intensity. $R$ \& D Management, 44, 248-264. http://dx.doi.org/10.1111/radm.12065

[9] Jenssen, J.I. and Nybakk, E. (2013) Inter-Organizational Networks and Innovation in Small, Knowledge-Intensive Firms: A Literature Review. International Journal of Innovation Management, 17, 27.

[10] Teece, D.J. (1993) Profiting from Technological Innovation: Implications for Integration, Collaboration, Licensing and Public Policy. Research Policy, 22, 285-305. http://dx.doi.org/10.1016/0048-7333(93)90063-n

[11] Dosi, G. (1982) Technological Paradigm and Technological Trajectories: A Suggested Interpretation of the Determinants and Directions of Technological Change. Research Policy, 22, 102-103. http://dx.doi.org/10.1016/0048-7333(82)90016-6 